\title{
Immunomagnetic purification of beta cells from rat islets of Langerhans
}

\author{
V.Hadjivassiliou ${ }^{1}$, M.H. L. Green ${ }^{2}$, I. C. Green ${ }^{2}$ \\ ${ }^{1}$ Biochemistry Department, University of Sussex, Brighton, UK \\ ${ }^{2}$ School of Pharmacy and Biomolecular Sciences, University of Brighton, Brighton, UK
}

\begin{abstract}
Aims/hypothesis. The aim of this study was to develop immunomagnetic purification by the Dynabead system to separate insulin-containing beta cells from a mixed rat islet cell population. Functional studies on insulin secretion and a test of the susceptibility of Dynabead-separated beta cells to DNA damage following cytokine exposure were carried out.

Methods. Dynabeads are uniform, paramagnetic particles coated with specific antibodies. Single rat islet cells were initially incubated with the beta-cell surface specific antibody (K14D10 mouse $\mathrm{IgG}$ ) for 20-60 min. A suspension of Dynabeads coated with a secondary antibody (anti-mouse IgG) was added for a further $15 \mathrm{~min}$, after which the Dynabead-coated cells were instantaneously pelleted by contact between the tube and a magnet (Dynal MPC). Immunocytochemistry was used to confirm that the Dynabead-coated cells contained insulin and to quantify the efficiency of the method. Dynabead-coated and
\end{abstract}

non-coated cells were stained for insulin and glucagon.

Results. Dynabead immunopurification yielded $95 \%$ pure insulin-containing beta cells, which released insulin in response to isobutylmethylxanthine and glucagon-like polypeptide 1 . The insulin content of Dynabead-coated beta cells was significantly higher than that of non-coated cells. Successful separation was achieved using as few as 30 islets as starting material. Using the comet assay, we found that Dynabeadcoated beta cells showed equal susceptibility to cytokine-induced DNA damage as non-coated cells.

Conclusion/interpretation. We conclude that Dynabead separation of beta cells is simple, rapid, applicable to large or small numbers of islets and can be used to study beta-cell specific function and responsiveness. [Diabetologia 2000 43: 1170-1177]

Keywords Beta cells, islets of Langerhans, Dynabead, purification, cytokines, comet assay.
Immunomagnetic separation of a range of different cell types (blood cells, immune cells, endothelial cells, neural cells) from heterogeneous populations by Dynabeads is well documented [1-4]. Dynabeads

Received: 24 January 2000 and in revised form: 17 May 2000

Corresponding author: V. Hadjivassiliou, Biochemistry Department, School of Biological Sciences, University of Sussex, Brighton BN1 9QG, East Sussex, UK

Abbreviations: Dynal MPC: Dynal magnetic particle concentrator, FITC: fluorescein isothiocyanate, IBMX: isobutyl-1methylxanthine, GLP-1: glucagon-like polypeptide 1 , IL-1 $\beta$ : interleukin- $1 \beta$, IFN- $\gamma$ : interferon- $\gamma$, FACS: fluorescence-activated cell sorting. are uniform, superparamagnetic, polymer particles, coated with specific antibodies; they can be added to a heterogeneous cell suspension in which they bind to the desired target cells. The resulting complex can be removed from the suspension using a Dynal magnetic particle concentrator (Dynal MPC).

Identification and separation of beta cells from a mixed islet cell population is desirable because gene expression, protein expression and responses specific to beta cells can be monitored. In this investigation Dynabead technology has been used as a means to separate beta cells that contain insulin from a population of mixed rat islet cells. We also looked at whether the cells separated by Dynabeads responded to 
stimuli for insulin secretion. We have previously shown that cytokines cause DNA damage in rat islets $[5,6]$ but it is not known whether this is specific to beta cells. We have used immunomagnetic separation to investigate the susceptibility of beta cells purified by Dynabeads to DNA damage after exposure to cytokines.

\section{Materials and methods}

Rat islet isolation. Islets of Langerhans were isolated from female Sprague-Dawley rats (180-250 g) by ductal injection of pancreas with collagenase (Type X1) (Sigma Aldrich, Poole, UK). Islets were either used immediately or cultured, for times stated in Results, in 60-mm Petri dishes with RPMI 1640 medium (Life Technologies, Paisley, UK) containing glucose $(5.5 \mathrm{mmol} / \mathrm{l})$, fetal calf serum $(5 \% \mathrm{v} / \mathrm{v})$, penicillin $(50 \mathrm{U} / \mathrm{ml})$ and streptomycin $(50 \mu \mathrm{g} / \mathrm{ml})$.

Islet cell separation. Rat islets, as few as 30, were made into single cells with $1 \mathrm{ml}$ of a solution of Accutase used as supplied by the manufacturers (TCS Biologicals, Buckingham, UK). The islets were incubated at $37^{\circ} \mathrm{C}$ and dispersed regularly using a micropipette until they were made into single cells (20-25 min). The digestion time was much longer than that used previously with trypsin (1 min) [6] and the cells were not removed from the Accutase solution until isolation was complete. Separated islet cells were centrifuged at $200 \times g$ for 5 min and the supernatant discarded.

Beta-cell separation. We used Dynabeads M-450 (Dynal, Liverpool, UK) for the immunomagnetic separation of beta cells. Dynabeads were supplied as a suspension containing $4 \times 10^{8}$ beads $/ \mathrm{ml}$ with a diameter of $4.5 \mu \mathrm{m} /$ bead and were covalently bound to affinity-purified sheep anti-mouse $\mathrm{IgG}$ which can recognise and bind the K14D10 mouse IgG [7-9]. Before use, the Dynabeads were washed in phosphate-buffered saline (PBS), $\mathrm{pH} 7.5$, and resuspended at a final concentration of $0.8 \times 10^{7}$ beads $/ \mathrm{ml}$ in RPMI medium. The single islet cell pellet was resuspended and dispersed in $25 \mu \mathrm{l}$ of the primary antibody K14D10. Different concentrations of primary antibody and different incubation times $(20 \mathrm{~min}-2 \mathrm{~h})$ were used to establish optimum binding. Cells were routinely incubated with the K14D10 antibody for $1 \mathrm{~h}$ on ice with frequent mixing. The unbound antibody was discarded after centrifugation of cells at $200 \times g$ for $5 \mathrm{~min}$. Antibody-bound cells were then washed twice in RPMI medium and the cell pellet resuspended and dispersed in $150 \mu \mathrm{l}$ of the Dynabead anti-mouse IgG solution. Cells were incubated with the Dynabeads for $15 \mathrm{~min}$ on ice, with gentle mixing, after which the tube was placed in a Dynal magnetic particle concentrator (Dynal MPC, Dynal); other magnets could also be used. After $60 \mathrm{~s}$ the supernatant was removed into another tube, leaving the positively selected cells attached to the side of the tube. The tube containing the supernatant was placed in the magnet again and the separation was repeated to ensure recovery of all Dynabead-coated cells. Dynabead-coated cells and non-coated cells were washed and resuspended in RPMI medium. An aliquot from the Dynabeadseparated sample was transferred to a microscope slide and photographed on an inverted light microscope (Olympus, Tokyo, Japan).

The K14D10 antibody is now commercially available from the L-A-D Laboratory of Autoimmune Diagnostic, Hennigsdorf, Germany.
Scanning electron microscopy. Dynabead-coated cells were fixed in $2.5 \%$ glutaraldehyde in phosphate-buffered saline (PBS, pH 7) and, while fixing, allowed to settle onto a 'thermanox' tissue culture coverslip (Miles Scientific, Naperville, Ill., USA) overnight at $4{ }^{\circ} \mathrm{C}$. After post-fixation in $1 \%$ osmium tetroxide in PBS for $2 \mathrm{~h}$ at room temperature, the cells were rinsed in distilled water, dehydrated in an ethanol series and then critical-point dried and sputter-coated with gold. The cells were examined in a Leo S420 scanning electron microscope (Leo Electron Microscope, Cambridge, UK) at $20 \mathrm{kV}$ with a probe current of $25 \mathrm{pA}$.

Immunocytochemistry for quantification of efficiency of Dynabead separation. We pelleted dispersed islet cells, Dynabeadcoated cells and non-coated cells, by centrifugation $(200 \times g$, $5 \mathrm{~min}$ ) or by placing them in the Dynal MPC and fixed them for $20 \mathrm{~min}$ in $4 \%$ formaldehyde at room temperature. The cells were washed twice and resuspended in $80 \mu \mathrm{l}$ of RPMI medium. Two aliquots of $40 \mu \mathrm{l}$ from each sample were transferred to two microscope slides coated with poly-L-lysine $(0.01 \%$, Sigma Aldrich, Poole, UK). After $1 \mathrm{~h}$ of incubation at room temperature in a humidified chamber, excess medium was removed and $40 \mu \mathrm{l}$ of $30 \%$ ethanol were added to the samples for $20 \mathrm{~min}$ at $-20^{\circ} \mathrm{C}$. We washed the slides in two changes of PBS for 5 min each wash and then exposed the cells to insulin and glucagon antisera. We used $40 \mu \mathrm{l}$ of either guinea-pig anti-insulin serum (a gift from A. J. Bone, University of Brighton, Brighton, UK) diluted 1:100 in PBS or rabbit anti-glucagon serum (Dako, Cambridgeshire, UK) diluted 1:100 in PBS. The procedure was carried out as described previously [10]. An anti-guinea-pig insulin antibody conjugated to fluorescein isothiocyanate (FITC) (Sigma Aldrich, Poole, UK), diluted 1:16 in PBS, was applied to the anti-insulin-treated samples and an anti-rabbit glucagon antibody conjugated to FITC, diluted 1:16 in PBS, was applied to the anti-glucagon-treated samples. For further identification of single cells by nuclear staining, we added Hoechst 33342 dye $(20 \mu \mathrm{g} / \mathrm{ml})$ (Calbiochem-Novabiochem, Nottingham, UK) to all samples for 15 min in a dark humidified chamber at room temperature, followed by two washes in PBS for 5 min each wash. Slides were viewed using a broad-band fluorescence filter set with an excitation wavelength range of $450-490 \mathrm{~nm}$ for cells containing staining insulin and glucagon and $365 \mathrm{~nm}$ for identifying nuclei which were counted to help to find the total cell number (especially of non-immunostained cells). Results for cells which were positive for insulin and glucagon are expressed as the percentage (\%) of cells stained positively with the Hoechst dye.

Hoechst/propidium iodide (HPI) staining. Propidium iodide entry into cells is a sensitive measure of membrane integrity. Cell suspensions, including those containing Dynabeads, were mixed on a microscope slide with equal volumes $(10 \mu \mathrm{l})$ of a dye mixture of Hoechst 33342 and propidium iodine (both at final concentration of $10 \mu \mathrm{g} / \mathrm{ml})$. The cells were viewed using a broad-band fluorescence filter set with an excitation wavelength of $365 \mathrm{~nm}$. Nuclei stained blue are in intact cells, nuclei showing red or pink coloration were recorded as propidium iodide positive and were in cells that are probably non-viable.

Measurement of insulin content. We monitored beta-cell isolation by measuring insulin in Dynabead-coated beta cells and non-coated islet cells. An aliquot was removed from dispersed islet cells before incubation with K14D10 antibody; a fraction was counted to measure cell concentration and insulin was extracted in $200 \mu \mathrm{l}$ of acid ethanol (concentrations: HCl:water:ethanol 0.45:7:23 v/v/v) overnight at $4{ }^{\circ} \mathrm{C}$. The number of cells in Dynabead-coated and non-coated cell populations 
was found by haemocytometer counting and insulin was extracted in $200 \mu \mathrm{l}$ of acid ethanol. The sample extracts were diluted (1:500 to 1:15000) and radioimmunoassayed for insulin. Insulin was assayed using rat insulin standards (Novo Nordisk, Copenhagen, Denmark), guinea-pig insulin antiserum and ${ }^{125} \mathrm{I}$ labelled bovine insulin [10]. Results for all cell populations were expressed as pg of insulin/cell.

Measurement of insulin secretory responses. Isolated islets were separated into single cells as described above. Insulin secretion from groups of cells (three replicates of $3 \times 10^{3}$ ) from a suspension of the mixed islet cell population was measured by challenging for $2 \mathrm{~h}$ at $37^{\circ} \mathrm{C}$ in $250 \mu \mathrm{l}$ of physiological buffer containing glucose $(20 \mathrm{mmol} / \mathrm{l}) \pm$ isobutyl-1-methylxanthine (IBMX, $0.5 \mathrm{mmol} / \mathrm{l}$ ) (Sigma) and \pm glucagon-like polypeptide 1 (GLP-1, $\left.10^{-7} \mathrm{~mol} / \mathrm{l}\right)$ (Peninsula Laboratories Europe, St. Helens, UK). We separated the beta cells by Dynabead, counted the Dynabead-coated cells and placed them in tubes $\left(3 \times 10^{3} /\right.$ tube) in which insulin secretory responses were tested. All cells were gently shaken during the incubation and tubes were subsequently centrifuged at $200 \times g$ for $5 \mathrm{~min} ; 200 \mu \mathrm{l}$ incubation medium was removed for insulin assay. The insulin that was stored in cells was extracted using acid ethanol and diluted for radioimmunoassay as stated above.

Cells from both the mixed and Dynabead-coated beta-cell populations were cultured in Falcon 48-well tissue culture plates (Marathon Laboratory Supplies, London, UK) for 3 days, without additional attachment factors, therefore not all cells adhered. At the end of the culture period RPMI was removed, unattached cells were conserved and insulin secretion measured after replacement with physiological buffer containing glucose, IBMX and GLP-1 challenges as above for freshly dispersed cells. This time, the insulin secretion tests were in the wells of 48 -well plates left at $37^{\circ} \mathrm{C}$ in a tissue culture incubator for $2 \mathrm{~h}$. After the $2 \mathrm{~h}$ the challenge media were removed and centrifuged for $5 \mathrm{~min}$ at $200 \times \mathrm{g}$. We retained $200 \mu \mathrm{l}$ of supernatant to measure secreted insulin. Cells from which secretion was determined were extracted for total insulin as above.

Treatment of rat islets with cytokines. We treated groups of up to 300 islets with cytokines in RPMI culture medium in 60$\mathrm{mm}$ Petri dishes and cultured them for $48 \mathrm{~h}$ at $37^{\circ} \mathrm{C}$ in an atmosphere of $5 \% \mathrm{CO}_{2}: 95 \%$ air before doing the comet assay analysis. The cytokines used were human recombinant interleukin$1 \beta$ [(IL-1 $\beta) 100 \mathrm{pmol} / \mathrm{l}, 21 \mathrm{U} / \mathrm{ml}]$ (a gift from Glaxo Wellcome, Stevenage, UK), human recombinant tumour necrosis factor$\alpha[(\mathrm{TNF}-\alpha) 100 \mathrm{pmol} / \mathrm{l}, 88 \mathrm{U} / \mathrm{ml}]$ (a gift from National Institute of Biological Standards and Control, Potters Bar, UK) and rat recombinant interferon- $\gamma[(\mathrm{IFN}-\gamma) 2 \mathrm{U} / \mathrm{ml}]$ (Genzyme, West Malling, Kent, UK).

Use of the comet assay to detect DNA strand breaks in Dynabead-coated beta cells. Single cell gel electrophoresis (the comet assay) was used to measure DNA strand breaks in single cells $[6,11]$. After islets had been treated with cytokine for $48 \mathrm{~h}$, islets were made into single cells using Accutase. We used single cells as a mixed cell population or as Dynabeadcoated beta cells or non-coated cells as described above and resuspended them in approximately $50 \mu \mathrm{l}$ culture medium. Slides for gel electrophoresis were set up with two layers of agarose $(0.6$ and $1.2 \%)$, with the cells embedded in the top layer $(0.6 \%$ agarose $)$. Approximately $5 \times 10^{4}$ cells from control or treated islets were used for each slide. The slides were placed in lysis solution $(2.5 \mathrm{~mol} / \mathrm{l} \mathrm{NaCl}, 100 \mathrm{mmol} / \mathrm{l}$ EDTA-Na $10 \mathrm{mmol} / \mathrm{l}$ TRIS, $200 \mathrm{mmol} / \mathrm{l} \mathrm{NaOH}, \mathrm{pH} \mathrm{10)}$ supplemented with $1 \%(\mathrm{v} / \mathrm{v})$ Triton X-100 and $10 \%(\mathrm{v} / \mathrm{v})$ dimethyl sulphox- ide (both Sigma) for $1 \mathrm{~h}$ at $4{ }^{\circ} \mathrm{C}$ to remove non-nuclear cell components. We allowed DNA to unwind during an alkaline treatment ( $20 \mathrm{~min}, 300 \mathrm{mmol} / \mathrm{l} \mathrm{NaOH}, 1 \mathrm{mmol} / \mathrm{l}$ EDTA-Na ${ }_{2}$ ) which causes an increase of the nuclear diameter to about $30 \mu \mathrm{m}$. Dynabeads, formerly attached to the beta-cell plasma membrane by antibody treatments, remained fixed in agar and coated the swollen nuclear DNA. Electrophoresis at $20 \mathrm{~V}$ for 24 min was then applied and DNA fragments moved towards the anode to form a comet tail. The slides were neutralised using TRIS buffer and the nuclei stained with ethidium bromide. Quantification of DNA damage was carried out using a fluorescence image analysis (Casys) system (Synoptics, Cambridge, UK) which compares the overall length of intact nuclei with damaged nuclei with a comet tail. The images were enhanced using the Casys system of Synoptics (Cambridge, UK) and we measured the mean comet length.

Statistical analysis. Results were calculated for individual experiments and the mean and standard error of these values were used. Data was subjected to Student's unpaired $t$ test and $p$ values of less than 0.05 were considered to be statistically significant.

\section{Results}

Efficiency of separating beta cells by Dynabead. Dynabead immunopurification of rat islet beta cells was achieved using the beta-cell surface antibody K14D10 and Dynabeads coated with anti-mouse IgG. Initially we incubated cells for $10,20,30,60$ or 120 min with the K14D10 antibody diluted 1:5, 1:10, 1:20 and 1:50 to optimise beta-cell recovery. We also tested different concentrations of Dynabeads, from $0.8 \times 10^{7}$ beads $/ \mathrm{ml}$ up to $3 \times 10^{7}$ beads $/ \mathrm{ml}$, to find a concentration at which the cells were definitively but not totally covered with beads. The number of cells coated with Dynabeads increased with increasing K14D10 antibody concentration. When high concentrations of Dynabeads were tested, beta cells were thickly covered with beads whereas the lower concentration $\left(0.8 \times 10^{7}\right.$ beads $\left./ \mathrm{ml}\right)$ gave an average of 6 beads/cell without altering the number of isolated beta cells. For these reasons, we routinely used K14D10 antibody incubation for $1 \mathrm{~h}$ and a final concentration of $0.8 \times 10^{7}$ beads $/ \mathrm{ml}$. Dynabead-coated beta cells are illustrated in Figure 1. The efficacy of beta-cell isolation varied from 24 to $46 \%$ from the mixed cell population, with a mean of $34 \pm 3$ for eight measurements. This can be improved further by the use of a more specific second antibody. Dynabeads, seen as small, black spheres, surround the bigger, paler beta cells in a light microscope photograph (Fig. 1). An average of six beads/cell can be seen. Scanning electron microscopy shows a beta cell surrounded by four smooth, spherical Dynabeads (Fig. 1).

To quantify the efficiency of separating beta cells by Dynabeads we applied insulin and glucagon antisera to mixed islet cells, Dynabead-coated cells and non-coated cells. The percentage of insulin-containing cells in beta cells separated by Dynabeads signifi- 

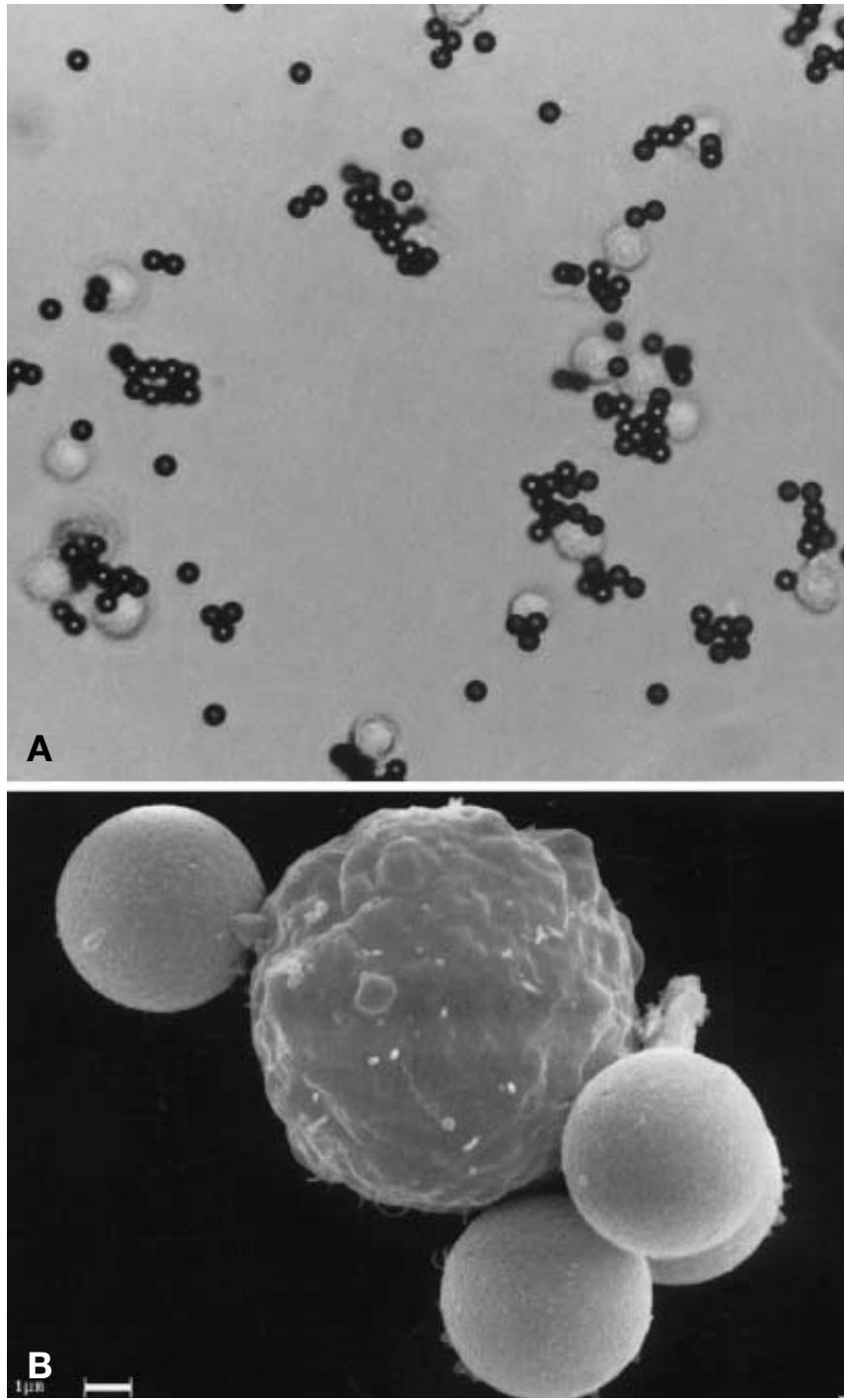

Fig. 1A, B. Dynabead immunopurified rat islet beta cells seen (A) by light microscopy and (B) by scanning electron microscopy. Isolated rat islets were made into single cells and separated into Dynabead-coated cells (see Methods). A Beta cells are surrounded by Dynabeads (average six beads/cell) $\times 400$. B A Dynabead-coated beta cell, $\times 14,000$

cantly increased and the percentage of glucagon-containing cells decreased, compared with that in dispersed islet cells (Fig.2). A small number of insulinstained cells $(8.5 \pm 3.2 \%)$ could be seen in the noncoated cell population. A mixed islet cell population was also stained for insulin and glucagon; $57.9 \pm 2.5 \%$ of intact cells were beta cells and about $24.8 \pm 3.1 \%$ were alpha cells (Fig. 2 ).

We measured the insulin content of Dynabeadcoated cells and non-coated cells to validate the separation of beta cells by Dynabeads. We found the insulin content of Dynabead-coated cells, separated from islets, freshly-isolated or cultured for 24 or $48 \mathrm{~h}$, was significantly higher than that of non-coated cells (Fig.3). The insulin content of beta cells separated by

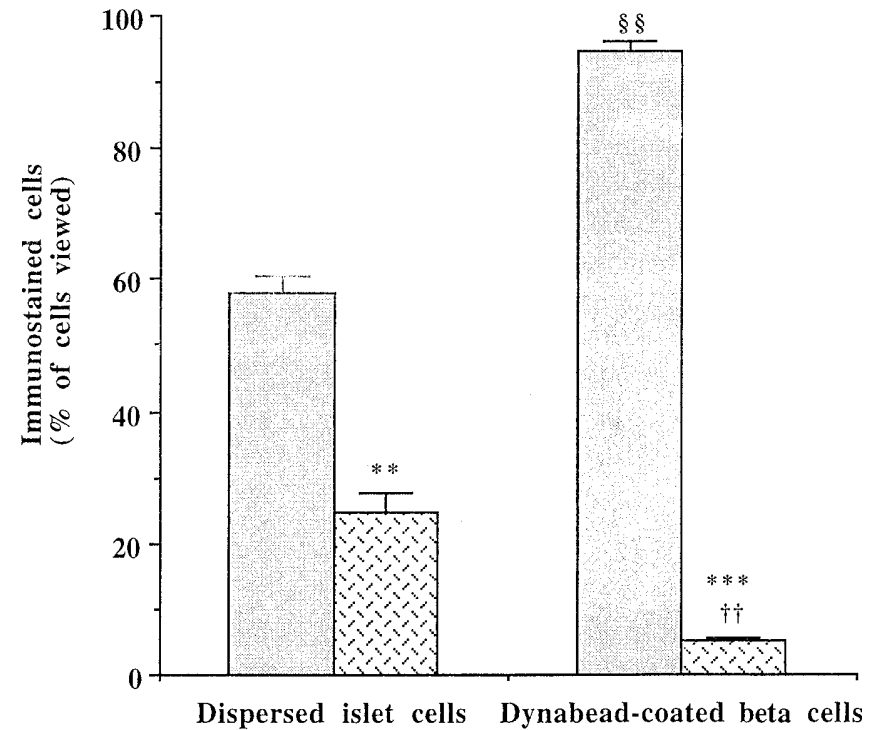

Fig. 2. Insulin and glucagon staining of dispersed islet cells and Dynabead-coated beta cells. Hormone-positive cells were counted and results are expressed as the percentage of all cells present, as confirmed by Hoechst 33342 nuclear staining $(\% \pm \mathrm{SEM})(n=3)$. Cells containing glucagon ( were fewer than those containing insulin $(\square)$ in each population $(* *$ $p<0.01$, *** $p<0.001)$. In the Dynabead-coated cell fraction, there was a decrease in cells containing glucagon $(\dagger \dagger p<0.01)$ and an increase in the beta cells containing insulin $(\S \S$ $p<0.01)$ vs in dispersed islet cells

Dynabeads from cultured islets was lower, as expected, than the values obtained from Dynabead-coated beta cells separated from freshly isolated islets (Fig. 3).

Insulin secretion studies. Insulin secretion from populations of mixed islet cells, Dynabead-coated and non-coated cells was measured immediately after preparation and after cell culture for 3 days (Fig. 4). The results for mixed islet cells showed stimulation of secretion in response to $20 \mathrm{mmol} / \mathrm{l}$ glucose and further significant secretory responses, as expected, to IBMX and GLP-1 (Fig.4). The Dynabead-coated beta-cell population responded to agents which increase cyclic AMP but not to glucose on its own (Fig.4). The non-coated cell population, which contained contaminating beta cells, had an insulin content of $4.0 \pm 0.5 \mathrm{pg} /$ cell compared with $14.2 \pm 1.4 \mathrm{pg}$ insulin/Dynabead-coated cultured cell and showed unregulated insulin release. Some of the unrecovered beta cells could have been damaged in such a way that plasma membrane binding of K14D10 antibody did not occur.

Mixed rat islet cells in experiments in the past in our laboratory showed propidium iodide uptake of $10.5 \pm 3.2 \%, n=6$ or $15.1 \pm 3.1 \%, n=8$, i.e. 89.5 to $84.9 \%$ 'viability'. Viability of mixed islet cells in the series of five experiments for insulin secretion measurement was suboptimal, $76.6 \pm 2.2$. It is, however, 


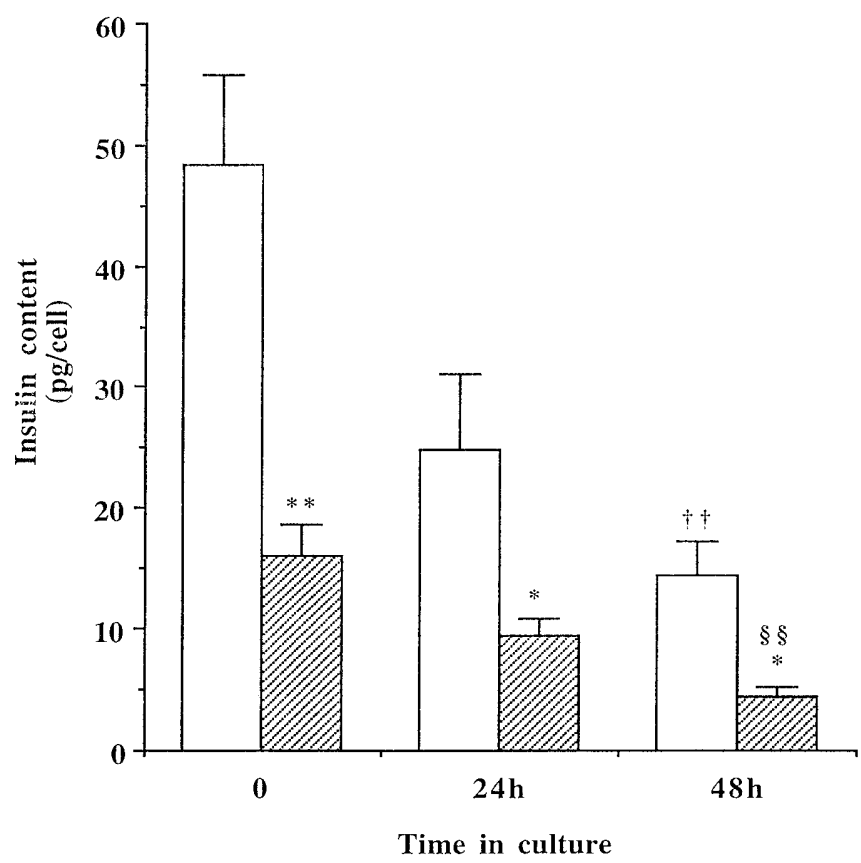

Fig.3. Insulin content of Dynabead-separated beta cells and non-coated cells. Results are expressed as pg of insulin/cell \pm SEM $(n=3)$. Insulin content of each non-coated cell (Z) was lower $(* p<0.05, * * p<0.01)$ vs result obtained from Dynabead-coated cells $(\square)$ (same culture time). Insulin content was lower in Dynabead-coated cells $(\dagger \dagger p<0.01)$ and noncoated cells $(\$ \S p<0.01)$ from 48 -h-cultured vs freshly isolated islets, respectively

clear that Dynabead attachment did not lower viability which was $72.9 \pm 1.8 \% n=5$. These values are consistent with the large 'basal' insulin secretion in response to incubation with $2 \mathrm{mmol} / \mathrm{l}$ glucose (Fig. 4).

For most purposes, separation of beta cells could take place after, rather than before, culture treatments. We attempted, however, to culture all three cell classes without use of polylysine, collagen or other substrates in 48-well Falcon plates; cell viability in each group decreased by a further $15 \%$ in culture. After 3 days, the insulin secretory responses of all the cells added to the culture wells were measured during a 2-h challenge. Significant secretory responses to IBMX and GLP-1 were obtained in both mixed islet cells and Dynabead-coated beta cells; there was, however, no response of either cell type to glucose alone (Fig.4). Non-coated cells, which are largely non-beta cells, failed to recover any insulin secretory capability (result not shown).

DNA damage studies. Treatment of rat islets for $48 \mathrm{~h}$ with a combination of cytokines resulted in significant DNA strand-breakage in the mixed islet cell population (Table I). Control and cytokine-treated islet cells were separated into viable Dynabead-coated beta cells and non-coated cells. We found that cytokine-treated beta cells showed equal susceptibility to
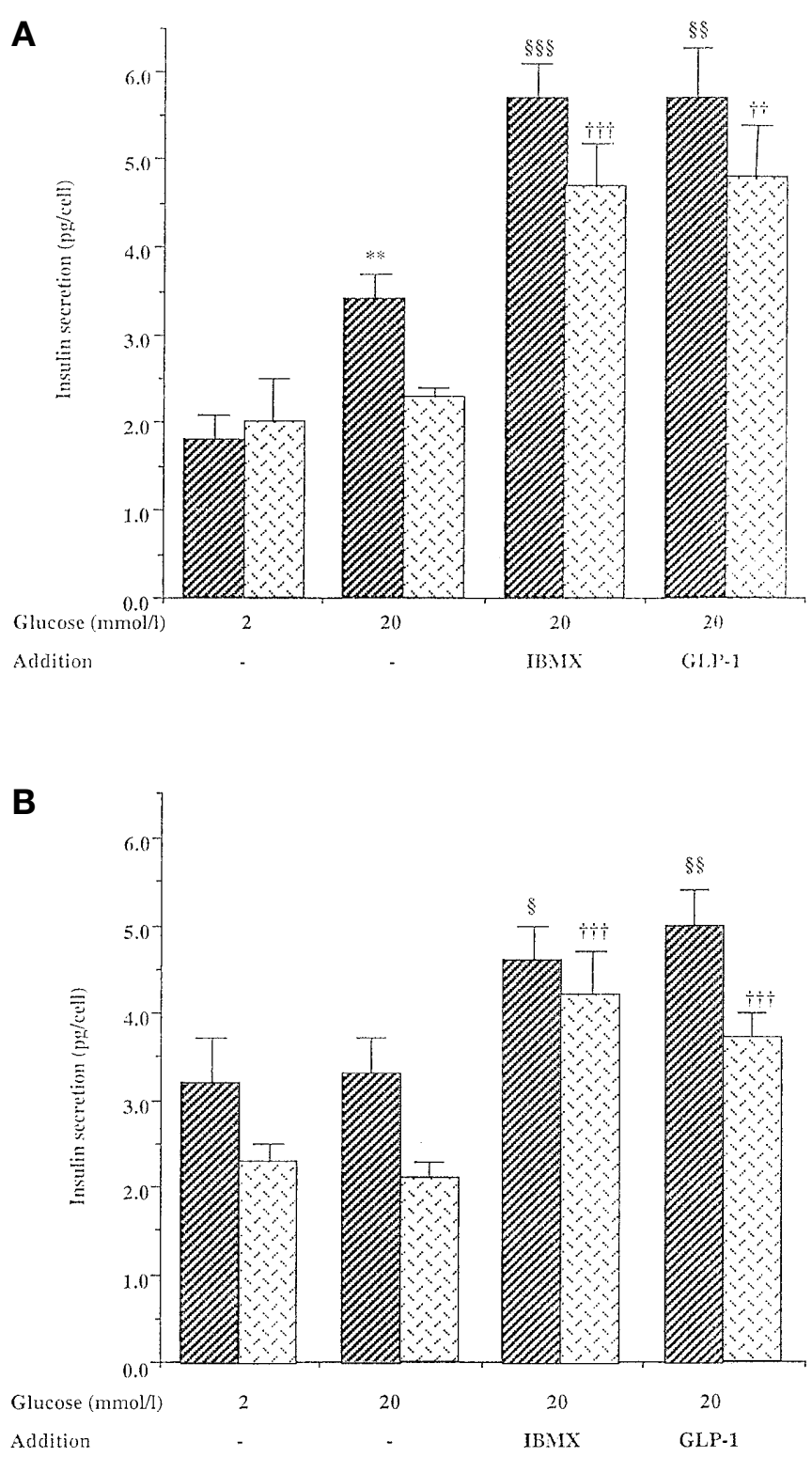

Fig. 4A, B. Insulin secretory responses of dispersed islet cells (U) and Dynabead-coated beta cells ( Groups of $3 \times 10^{3}$ cells from each population were used for measurement of insulin secretion immediately after isolation (A) or after 3 days in culture without attachment factors $(\mathbf{B})$. Results are expressed as pg of insulin/cell $\pm \operatorname{SEM}(n=4-5)$. The dispersed islet cell population showed stimulation of insulin secretion in response to $20 \mathrm{mmol} / 1$ glucose ( $* * p<0.01 \mathrm{vs} 2 \mathrm{mmol} / 1$ glucose) and further stimulation after treatment with IBMX and GLP-1 ( $\$ p<0.05, \S \S p<0.01, \S \S \S p<0.001$ vs $20 \mathrm{mmol} / \mathrm{l}$ glucose). Dynabead-coated beta cells similarly responded to IBMX and GLP-1 (†† $p<0.01, \dagger \dagger \dagger p<0.001$ vs $20 \mathrm{mmol} / 1$ glucose)

DNA damage as non-coated cells (Table I). Previous studies from our group using the K14D10 antibody and fluorescence-activated cell sorting (FACS) analysis showed that there was no difference in the percentage of cells bound to the beta-cell surface antibody between control and cytokine-treated neonatal rat islets (control $91.0 \pm 2.4 ;$ IL- $1 \beta$-treated $90.1 \pm 1.5$; 
Table 1. DNA damage responses of mixed islet cells, Dynabead-coated beta cells and non-coated cells

Comet length. Diameter of nucleus plus comet tail $(\mu \mathrm{m})$

\begin{tabular}{lll} 
& Control & 3 cytokines \\
\hline Dispersed islet cells & $23.4 \pm 0.9$ & $44.3 \pm 3.5^{\mathrm{a}}(4)$ \\
Dynabead-coated beta cells & $24.4 \pm 1.1$ & $43.7 \pm 2.7^{\mathrm{a}}(5)$ \\
Non-coated cells & $22.8 \pm 0.6$ & $46.2 \pm 3.6^{\mathrm{a}}(5)$
\end{tabular}

After 48-h treatment with a combination of cytokines rat islets were made into single cells and used, in the comet assay, as mixed islet cells or separated into Dynabead-coated cells and non-coated cells as described in Methods. Results are the length $(\mu \mathrm{m})$ of the nucleus plus comet tail \pm SEM. The number of experiments is shown in parenthesis. ${ }^{a} p<0.001$ vs control untreated islet cells

TNF- $\alpha$-treated $90.0 \pm 0.05 ;$ IFN- $\gamma \quad 88.6 \pm 4.0 ;$ three combined cytokine-treated $89.6 \pm 2.3$, from three to six experiments). This indicates that treating islets with cytokine does not influence binding of the betacell surface antibody to its antigen.

\section{Discussion}

In this study we show that beta cells can be isolated from a dispersed heterogeneous population of islet cells using Dynabead technology. Separation can also be achieved by FACS [12-15], which yields $90-98 \%$ pure beta cells and $80-85 \%$ alpha cells containing $5-10 \%$ contamination by beta and delta cells $[12,16,17]$. The purity of the beta-cell population obtained by immunomagnetic separation is similar to that reported for beta cells purified by FACS [12, 16-18]. The recovery rates from the mixed cell population of less than $50 \%$ are not as good as reported [18], but can be improved. Immunomagnetic separation is a simple and reliable technique and separation can be achieved in a short time, from a small number of islets, if desired and from freshly isolated as well as cultured islets. In principle, any beta-cell surface specific antibody can be used; if avidity is low, fewer cells might be recovered.

Insulin secretory responses of mixed islet cells and Dynabead-coated cells show that single beta cells lose their secretory responsiveness to glucose, but respond to agents which increase cyclic AMP [18]. The basal insulin release could be due to using islets freshly isolated by collagenase. Accutase used in the preparation of single cells is without trypsin and is said to cause no damage to human endothelial cells even during 2-h incubation (Manufacturer's instructions). It provides single cells in excellent condition for the comet assay [6], its use in islet cell preparation has, however, not been fully explored. It is noteworthy that the single cells coated with primary and secondary antibodies and with magnetic Dynabeads can respond to agonists such as GLP-1 which act through plasma membrane receptors. Cytokines, such as interleukin- $1 \beta$, tumour necrosis factor- $\alpha$, and interferon- $\gamma$, have been proposed to participate in the dysfunction and destruction of pancreatic islets [19]; nitric oxide has been implicated as an effector molecule responsible for some cytokine effects [6, 20-23]. Interleukin-1 $\beta$ (IL-1 $\beta$ ) has been shown to induce nitric oxide formation from FACS-purified beta but not alpha cells $[13,24]$, possibly through type I IL- $1 \beta$ receptors [12]. Interleukin- $1 \beta$-induced inhibition of insulin secretion and glucose oxidation of purified beta cells has also been studied, implicating the beta cell as a source of IL- $1 \beta$-induced nitric oxide production whereas IL- $1 \beta$ was shown not to affect alpha-cell metabolic activity $[12,13,25]$.

In our study we investigated the susceptibility of beta cells to DNA damage after treating intact islets for $48 \mathrm{~h}$ with a combination of cytokines. The DNA damage assay uses single cells, therefore dispersion after cytokine treatment, whether of intact islets or separated adherent single cells, cannot be avoided $[6,26,27]$. Whole islet rather than isolated single cell treatments can give results which are different [28] and arguably might better reflect beta-cell physiology. Whole islet culture has been used invariably in the past for comet assay analysis of cytokine effects. Cell recovery is not an issue because islets are only minimally digested (for $45 \mathrm{~s}$ ) to give sufficient single cells of high quality to subject to single cell gel electrophoresis [6]. Here we showed that Dynabead-coated cells, non-coated cells and dispersed islet cells were equally susceptible to DNA damage by cytokines. We have shown previously that short-term cytokine treatment involves nitric oxide-mediated DNA damage $[5,6,27]$. A recent study [29] using immunocytochemistry and confocal microscopy of rat islets found the expression of inducible nitric oxide synthase (iNOS) not only in insulin-producing beta cells but also in some glucagon-producing alpha cells and pancreatic polypeptide PP-cells.

Dynabead-coated beta cells can be used to study a variety of beta-cell specific responses. They have the potential to be used in gene expression studies because Dynabeads are compatible with polymerase chain reaction (PCR) conditions; the beads do not leak iron into the reaction mixture which would inhibit the PCR reaction. Because isolation time is short, Dynabead-purified beta cells could be used in short-term studies of ion movement or cell signalling. If required, Dynabeads can, however, be removed from the target cells using DETACHaBEAD (Dynal). This detachment system has been developed to release Dynabeads from haemopoetic cells and lymphocytes and also detach certain secondary-coated Dynabeads from cells coated with different monoclonal antibodies. According to the manufacturers, detachment of Dynabeads can also be achieved by overnight incubation of the coated cells at $37^{\circ} \mathrm{C}$ fol- 
lowed by pipetting of the suspension a few times through a narrow-tipped pipette, although the effectiveness of detachment decreases as the number of Dynabeads binding to the cells increases. We suggest that the efficacy of recovery of beta cells from mixed islet cell populations can be improved by the use of (1) protease inhibitors after cell isolation and during antibody application, (2) a more specific second antibody, i. e. IgG2 a or 2ak; (3) using mechanical dispersion to lower Accutase incubation time and (4) if culture is used to apply additional cell attachment substrates.

We conclude that immunomagnetic separation of beta cells using Dynabeads is feasible, simple and rapid with the potential to prepare cells from any number of islets and to amplify and accelerate studies of beta-cell specific functions.

Acknowledgements. We would like to thank Dr M. Ziegler, Pathophysiology Institute, University of Greifswald, Germany, for the gift of the K14D10 monoclonal antibody (now available commercially, see Methods), Dr A. Dunger from the Diabetes Institute, "Gerhard Katsch", Karlsburg, Germany for invaluable collaboration, Dr J. Thorpe, University of Sussex for doing the scanning electron microscopy of Dynabead coated cells, A. Cooke, University of Brighton for excellent laboratory assistance and to acknowledge financial help from the German Academic Exchange Service (project number 733).

\section{References}

1. Flø RW, Nœss A, Lund-Johansen F et al. (1991) Negative selection of human monocytes using magnetic particles covered by anti-lymphocyte antibodies. J Immunol Methods 137: 89-94

2. Hansel TT, Pound JD, Pilling D et al. (1989) Purification of human blood eosinophils by negative selection using immunomagnetic beads. J Immunol Methods 122: 97-103

3. Hewett PW, Murray JC (1993) Immunomagnetic purification of human microvessel endothelial cells using Dynabeads coated with monoclonal antibodies to PECAM-1. Eur J Cell Biol 62: 451-454

4. Manyonda IT, Soltys AJ, Hay FC (1992) A critical evaluation of the magnetic cell sorter and its use in the positive and negative selection of $\mathrm{CD} 45 \mathrm{RO}+$ cells. J Immunol Methods 149: 1-10

5. Delaney CA, Green MH, Lowe JE, Green IC (1993) Endogenous nitric oxide induced by interleukin- $1 \beta$ in rat islets of Langerhans and HIT-T15 cells causes significant DNA damage as measured by the 'comet' assay. FEBS Lett 333: 291-295

6. Hadjivassiliou V, Green MH, James RF, Swift SM, Clayton HA, Green IC (1998) Insulin secretion, DNA damage and apoptosis in human and rat islets of Langerhans following exposure to nitric oxide, peroxynitrite and cytokines. Nitric oxide: Biology and Chemistry 2: 429-441

7. Ziegler B, Lucke S, Köhler E et al. (1992) Monoclonal antibody-mediated cytotoxicity against rat beta cells detected in vitro does not cause beta-cell destruction in vivo. Diabetologia 35: 608-613

8. Schlosser M, Witt S, Fürll B, Ziegler B, Ziegler M (1991) Different multiple reactivity of monoclonal islet cell bind- ing antibodies using indirect immunofluorescence technique on viable cells or cellular ELISA on desiccated cells as target. Diabetes Res 17: 147-155

9. Kuttler B, Wanka H, Hahn H-J (1997) Co-culture of pancreatic islets and allogeneic lymphocytes. Transplantation 64: $480-489$

10. Khawaja XZ, Bailey CJ, Thorpe J, Green IC (1990) Increased sensitivity to the insulin-releasing and glucoregulatory effects of dynorphin and $\mathrm{U} 50,488 \mathrm{~h}$ in genetically obese (ob/ob) versus lean mice. Diabetes 39: 1289-1298

11. Green MH, Lowe JE, Harcourt SA et al. (1992) UV-C sensitivity of unstimulated and stimulated human lymphocytes from normal and xeroderma pigmentosum donors in the comet assay: A potential diagnostic technique. Mutation Res 273: 137-144

12. Scarim AL, Arnush M, Hill JR et al. (1997) Evidence for the presence of type I IL- 1 receptors on $\beta$-cells of islets of Langerhans. Biochem Biophys Acta 1361: 313-320

13. Corbett JA, Wang JL, Sweetland MA, Lancaster JR, McDaniel ML (1992) Interleukin- $\beta$ induces the formation of nitric oxide by $\beta$-cells purified from rodent islets of Langerhans. J Clin Invest 90: 2384-2391

14. Strandell E, Buschard K, Saldeen J, Welsh N (1995) Interleukin- $1 \beta$ induces the expression of HSP70, heme oxygenase and Mn-SOD in FACS-purified rat islet $\beta$-cells, but not in $\alpha$-cells. Immunol Lett 48: 145-148

15. Ling Z, In't Veld PA, Pipeleers DG (1993) Interaction of interleukin-1 with islet beta cells. Distinction between indirect, aspecific cytotoxicity and direct, specific functional suppression. Diabetes 42: 56-65

16. Corbett JA, McDaniel ML (1995) Intraislet release of interleukin 1 inhibits $\beta$ cell function by inducing $\beta$ cell expression of inducible nitric oxide synthase. J Exp Med 181: $559-568$

17. Wang JL, McDaniel ML (1990) Secretagogue-induced oscillations of cytoplasmic $\mathrm{Ca}^{2+}$ in single $\beta$ - and $\alpha$-cells obtained from pancreatic islets by fluorescence-activated cell sorting. Biochem Biophys Res Commun 166: 813-818

18. Pipeleers DG, Schuit FC, In'tVeld PA et al. (1985) Interplay of nutrients and hormones in the regulation of insulin release. Endocrinology 117: 824-833

19. Mandrup-Poulsen T, Helqvist S, Wogensen LD et al. (1990) Cytokines and free radicals as effector molecules in the destruction of pancreatic $\beta$ cells. In: Baekkeskov S, Hansen B (eds) Human diabetes - genetic, environmental and autoimmune etiology; Current topics in microbiology and immunology, Springer, Berlin, Heidelberg, New York, pp 166-193

20. Southern C, Schulster D, Green IC (1990) Inhibition of insulin secretion by interleukin- $1 \beta$ and tumour necrosis factor- $\alpha$ via an L-arginine-dependent nitric oxide generating mechanism. FEBS Lett 276: 42-44

21. Corbett JA, Lancaster JR, Sweetland MA, McDaniel ML (1991) Interleukin-1beta-induced formation of EPR-detectable iron-nitrosyl complexes in islets of Langerhans. J Biol Chem 266: 21351-21354

22. Green IC, Cunningham JM, Delaney CA, Elphick MR, Mabley JG, Green MHL (1994) Effects of cytokines and nitric oxide donors on insulin secretion, cyclic GMP and DNA damage: relation to nitric oxide production. Biochem Soc Trans 22: 30-37

23. Di Matteo MA, Loweth AC, Thomas S et al. (1997) Superoxide, nitric oxide, peroxynitrite and cytokine combinations all cause functional impairment and morphological changes in rat islets of Langerhans and insulin-secreting cell lines but dictate cell death by different mechanisms. Apoptosis 2: 164-177 
24. Corbett JA, Kwon G, Misko TP, Rodi CP, McDaniel ML (1994) Tyrosine kinase involvement in IL- $\beta$-induced expression of iNOS by $\beta$ cells purified from islets of Langerhans. Am J Physiol 267: C48-C54

25. Hoorens A, Pipeleers D (1999) Nicotinamide protects human beta cells against chemically-induced necrosis, but not against cytokine-induced apoptosis. Diabetologia 42: $55-59$

26. Delaney CA, Pavlovic D, Hoorens A, Pipeleers DG, Eizirik DL (1997) Cytokines induce deoxyribonucleic acid strand breaks and apoptosis in human pancreatic islet cells. Endocrinology 138: 2610-2614
27. Dunger AM, Cunningham J, Delaney CA et al. (1996) Tumour necrosis factor- $\alpha$ and interferon- $\gamma$ inhibit insulin secretion and cause DNA damage in unweaned-rat islets. Extent of nitric oxide involvement. Diabetes 45: 183-189

28. Pavlovic D, Chen MC, Dysemans CA, Mathieu C, Eizirik DL (1999) The role of interferon regulatory factor-1 in cytokine-induced mRNA expression and cell death in murine pancreatic beta cells. Eur Cytokine Netw 10: 403-411

29. Alm P, Ekström P, Henningsson R, Lundquist I (1999) Morphological evidence for the existence of nitric oxide and carbon monoxide pathways in the rat islets of Langerhans: An immunocytochemical and confocal microscopical study. Diabetologia 42: 978-986 